\title{
Q: Since Marijuana Use Is Absolutely Prohibited Under Federal Law, Can An Employer Safely Fire An Employee Who Tests Positive For Cannabis? (A: Yes, No, Maybe, I Don't Know. Can You Repeat The Question?')
}

\author{
Darrell M. Crosgrove \\ The University of Toledo \\ Michael T. Zugelder \\ Old Dominion University \\ Kimberly Nigem \\ The University of Toledo \\ Donald K. Wedding \\ The University of Toledo
}

\begin{abstract}
Twenty-nine states and three US territories offer medical marijuana prescriptions for their citizens, with others considering such. Some of these states make it a violation to terminate an employee for medical marijuana use. Federal laws make any marijuana possession or use a crime, and in some instances, require a drug-free workplace. Should employers enforce drug screening rules, or relax their standards and permit employees with prescriptions for medical marijuana to test positive provided work product is not affected? And can relaxing these standards be presented as a benefit to both employees that use medical marijuana, and those who do not?
\end{abstract}

\section{FIRST, THE LEGAL LANDSCAPE}

Can an employer force employees to submit to mandatory drug screening even in states where marijuana has been decriminalized? Yes, they can, because a state's action of decriminalizing marijuana does not make it "legal" to use, but instead is that particular state saying, in effect, "We will no longer have this criminal law on our books." The end result is, as far as law enforcement actions by that state's officers go, the same as if marijuana had never been criminalized in that state-which means it is still illegal under federal law, and an employer can still terminate an employee that tests positive for marijuana even in states where medical marijuana is legalized and the employee has a prescription for medical marijuana (MM hereafter).

A leading case for that principle can be found in Coats v. Dish Network ${ }^{3}$. In Coats, Brandon Coats began working for Dish Networks in 2007. He then registered for, and received a state-issued license to use medical marijuana to help control painful muscle spasms caused by his quadriplegia. In May, 2009, 
Dish Networks subjected him to drug screening, and in June of 2010 he was terminated. He sued, arguing that under Colorado Law he was protected from termination for engaging in an activity which is considered lawful under Colorado law $^{4}$. In 2015 the Colorado Supreme Court ultimately decided that because federal law continues to make use of marijuana a crime without applicable exemption for Medical Marijuana, Dish Networks could fire him as Coats had engaged in an activity which was illegal under federal law.

Coats claim was based, not on Colorado's constitutional amendment decriminalizing MM, but on Colorado's "lawful activities" statute forbidding adverse employment consequences for employees off duty performance of those activities. By holding that the federal CDA criminalization of $m$ preempted any finding that off duty use of MM was "lawful", the court found the employee had no claim for wrongful termination. The result in Coats is consistent with most reported decisions on the issue. The cases have come from states like Colorado where the existing state law at the time (by constitutional amendment, referendum, statute or otherwise) decriminalized use of MM, but stopped short of addressing employment issues requiring drug testing exceptions for employees or imposing an obligation to accommodate use on employers ${ }^{5}$. Aside from the rationale that state law provides no separate basis for employees claims, these courts as the court in Coats, have also decided against employee claims based on the principle of federal preemption. So, the best legal advice for employers in these states is that an employer can fire an employee for marijuana use no matter the individual state's views on medical or recreational marijuana, as the employee was de facto in violation of federal law by using marijuana.

However, not all MM laws are alike and this advice may not be the best for employers in a growing minority of states where state law has gone beyond decriminalization and provide employees with a right to use and a basis to sue ${ }^{6}$. At least one court applying its state MM law has so held.

\section{Massachusetts Muddies the Water}

In Barbuto v. Advantage Sales \& Mktg., LLC ${ }^{7}$, Massachusetts Supreme Court slip opinion, July 18, 2017, a different decision was reached. In Barbuto, Cristina Barbuto became employed at Advantage Sales and Marketing (ASM) in the summer of 2014. She was told that she would have to take a mandatory drug test and she informed her employer that she would test positive for marijuana as she has a state approved certification that allows her to use marijuana for medical treatment of her Crohn's disease. She used it rarely, usually in the evening, and it would not interfere with her employment. Her employer told her that would not be a problem because she was a qualifying medical marijuana patient under Massachusetts law. On September 5, 2014, Barbuto submitted a urine sample. On September 11, 2014 she started work. That evening a different supervisor called her at home and told her that she was being terminated for having tested positive for marijuana. Barbuto reminded that supervisor that she had state approved permission to use medical marijuana, to which that supervisor replied "we follow federal law not state law."

The Supreme Court of Massachusetts could have reached the same decision that was reached in Coats, but instead found that Barbuto did have a cause of action to sue her employer as they had violated her rights under the law as Barbuto's physical condition created a disability which required her employer to try and make an accommodation for. Relying upon the language of the Massachusetts MM statute that registered users "not be penalized under Massachusetts law in any manner or deprived any right or privilege for such actions", the court decided that the law went beyond mere decriminalization to also affirmatively provide the employee with protection under separate state discrimination laws and a cause of action to sue the employer for refusing to accommodate an employee's use of MM for her medical condition. Thus, the employer had an affirmative duty to try and find an alternative treatment that would address the issue of Crohn's disease, and if none were available, the employer had a burden to prove that Barbuto's use of marijuana created a hardship on the employer which it could not reasonably be expected to accommodate. In short, the court firmly told her employer that unless her medical marijuana use actually interfered with her employment it should mind its own business and stay out of its employee's private life. 
The court in Barbuto also found no conflict between the Massachusetts MM law and the CDA and therefore no federal preemption which raises an interesting legal precedent. It does not say that employers are prohibited from enforcing federal laws through employment policies, but rather yields a rule that an employer does not have carte blanche to ignore state laws expressly prohibiting certain employer practices when there are no counterbalancing federal laws requiring contrary actions. Had ASM been required to enforce federal drug laws - such as if Barbuto had employment governed by industry or activity specific federal safety regulation (such as those of the DOT or FAA), then the federal regulations would be primary, state law would be preempted and Barbuto could be terminated. As discussed below, the situation is less clear where the employment is with a federal contractor. However, barring such employment and, in light of the duty given to employers by the legislature of the state of Massachusetts to make accommodations for people with disabilities, the affirmative duty given to the employer automatically outweighs the desire of employers to terminate people who test positive for medical marijuana use, as federal laws have not expressly given employers a duty to terminate people who test positive for marijuana. They might wish to do so, but federal law has not given them the duty, therefore they only have the duties given to the by Massachusetts, which prevents them from firing employees that have valid medical marijuana prescriptions.

As the Barbuto Court pointed out in its decision as of the time of its writing, "nearly ninety per cent of States, as well as Puerto Rico and the District of Columbia, allow the limited possession of marijuana for medical treatment." For employers inside of Colorado or Massachusetts, the question of whether or not you can terminate an employee for using medical marijuana appears to be very straightforward: Colorado - yes, Massachusetts - no.

For employers in all other states the question is more complicated, as without clear judicial guidance from their own courts, or statutes which specifically address said issues, it is anyone's guess how an individual state's court will decide on this issue. Arizona, Delaware, and Minnesota have passed laws prohibiting a medical marijuana using employee from being terminated solely for failing a urinalysis test, and statutes in as many as 11 states protect employee rights to use MM in one form or the other, but it is not known if their courts would ultimately decide along the lines of Coats or Barbuto.

\section{Q. How do Specific Federal and State Safety Rules Mandating Drug Free Workplaces and} Supporting Employer Drug Testing Impact on MM Workplace Issues of Non-Discrimination and Accommodation?

\section{A. They Can Clarify but also Further Complicate the Picture, Especially for Federal Contractor Employers.}

OSHA regulations cover nearly every employers and mandate safe working conditions. While there are no specific OSHA rule, drug impairment is covered by its general duty clause. Nothing in state or local law governing MM will waive employers' obligation to protect other employees and third parties in the workplace from danger caused by employee impairment due to a poorly administered MM policy. Risk of liability is expanded to suits brought by employees and the public in general via state tort laws that sanction employers for negligent hiring and retention of impaired employees ${ }^{8}$.

While a federally regulated employers obligation to comply with activity or industry specific federal law should continue to require preemption of any conflicting obligation to accommodate MM use under state MM law, obligations of employers with federal contracts to abide by state MM laws is less clear. The grants and penalties imposed by the Drug Free Workplace $\mathrm{Act}^{9}$ (DFWA) to terminate or exclude employees testing positive from MM use continues to apply to federal contracts, even though the Department of Labor ended the drug-free workplace program in 2010 and no longer administers its workplace drug testing advisory web page. That federal contract employers continue to bare the risk of contract debarment and other economic sanctions is evidenced by the language of several of the state MM statutes that mandate employer accommodation. Recognizing the conflict, they expressly exempt federal contractors from any duty to accommodate employee $\mathrm{m}$ use. Still the confusion has lead one legal commentator to advocate for Congress to enact a specific federal law providing federal contractor immunity from employee suits arising from state and local MM laws ${ }^{10}$. 


\section{Back to Benefits - Why Employers May Wish to Have Policies That Permit Reasonable Accommodations Allowing Medical Marijuana Use by Employees.}

First a few caveats. No employer, not even employers in Massachusetts, should ever permit marijuana use or possession on company property. To do so would violate federal law. Next, an employer should not be expected to tolerate someone whose use of medical marijuana interferes with their work product, although as with any legally disabled person, some slight lessening of the amount of work expected may be required. Furthermore, if an employee works in a field where safety concerns are an issue, or state or federal regulations come into play demanding totally 'clean' employees, those regulations would take precedent and could very well mean that the only reasonable accommodations allowed would be reassignment and reclassification of the employee to something not governed by such regulations ${ }^{11}$.

Public support for legal use of medical marijuana is currently at $83 \%$ of all Americans favoring permitting such ${ }^{12}$. That means that any employer that seeks to enforce marijuana laws via drug screening where it does not have to, is giving itself a public relations problem with $83 \%$ of possible employees and customers. This can be highlighted by what happened in the Coats case above, where overnight Dish Network became the international face of draconian corporate intolerance cracking down on Mr. Coats, who had a stellar work record despite his quadriplegia.

It is unfortunate that employers are left in a situation where they are left not knowing whether or not they have a legal right to terminate a medical marijuana using employee because of failed urinalysis test with the exception of employers in Colorado who know they can terminate such employees.

Examining the question from the opposite angle provides at least some clear guidance: "Can an employer safely do away with urinalysis for employees who have state issued permits for medical marijuana use where there are no public or regulatory safety concerns?"

The answer is "yes". Absent any regulations or safety concerns requiring that employees refrain from marijuana use $24 / 7$, even in their private lives, an employer has no duty to act as a voluntary monitor in enforcing federal marijuana laws. Companies like Dish Network may choose to have a corporate policy requiring employees abide by all federal laws even in their free time, but they are not required to do that. It is a corporate policy decision that Dish Network has made based upon their own weighing of the positives and negatives. This should not be construed as even implying that employers should tolerate compromised or "stoned" employees any more than they should tolerate employees who are drunk on the job - no employer should be expected to tolerate that.

That leaves employers in a situation where arbitrarily enforcing federal marijuana laws upon employees can land them in trouble civilly, depending on the statutes and judicial decisions of the state courts in which they are located: but those same employers are unlikely to ever face any legal challenges for not cracking down on employee home use of medical marijuana.

Again, this is a new and largely untested area of employment law, and consultation with a skilled employment law attorney in one's own state is prudent for any employers facing a situation where an employee may be using medical marijuana.

\section{How this can be Viewed and Presented as an Employee Benefit}

Now the discussion of dispensing with testing for, or at least tolerating employee use of medical marijuana as a benefit, can begin. A benefit is anything given to an employee which an employee is glad to receive and enhances their view of their working environment. Benefits range from paid vacation time to clean and private lactation rooms for nursing mothers. For an employee who is able to produce good work product but has a medical condition requiring the use of medical marijuana, an employer who would be willing to not subject them to urinalysis, and termination upon the inevitable failing of such a test, would probably be a major benefit in their eyes. It would also likely drive them to provide good work product so that they never risk termination or downsizing. It is, in effect, a benefit to employees who need to use medical marijuana, with no costs for the employer.

Furthermore, most employees want to work for employers that they feel good about helping. Employees want to feel good about the fact that their work helps a company which is helping others. Thus, a written corporate policy that reasonably permits recipients of medical marijuana to be exempt 
from testing for such is likely to earn good tidings from those $83 \%$ of Americans that feel medical marijuana should be legal. That means that people with no need for medical marijuana, but work for an employer that is tolerant of such, gain the benefit of working for an employer whose humanitarian views are in line with their own. And as above, it cost the employer nothing.

It is true that the same poll mentioned above did indicate that $14 \%$ of individuals oppose legalizing medical marijuana, and it is possible that a policy that tolerates home medical marijuana use could upset them. That means that each employer must decide, based upon its own business model, whether it wishes to be perceived as friendly towards medical marijuana recipients, or whether it wishes to be perceived as intolerant of such.

\section{Implementation}

As with any changes in policy coming from changes in the law, details matter. Leadership should take the following steps to assure that any tolerance of medical marijuana use is done properly:

1. Management should obtain a copy of the prescription (or other authorizing instrument used in their state) and keep it safely stored following all state and federal privacy laws.

2. A written waiver should be obtained from the employee permitting management to verify with the authorizing doctor that the prescription is valid.

3. A tickler system should be put in place to remind management when that prescription is going to expire.

4. At a time of 2-4 weeks prior to when the prescription is going to expire, the employee should be notified in writing of the fact that he or she is to provide a new prescription to management.

5. The employee should be notified, in writing of the fact that:

a. At no point should medical marijuana be brought onto company grounds, or to any off-facility corporate activities.

b. The employee must come to work sober every day, and remain sober at all times.

c. Management reserves the right to terminate the employee if they are involved with any other prohibited substances of any kind.

d. Should they be unable to come to work because of the medical marijuana use, the employer should be notified of such, so it may be annotated, and if available a sick day can be applied to that day.

6. The employee should be asked in writing if any other accommodations aside from waiving a failed urinalysis for marijuana are needed by the employee. The response, even if it is a simple "no" should be done in writing and signed by the employee. This should be done to fulfill the employer's duty to actively seek out all accommodations needed once the underlying medical condition requiring the use of medical marijuana is known by the employer $^{13}$.

7. While the employer can stop doing marijuana testing on employees who have met all requirements, it is probably prudent to continue to test the employee, to monitor for excessive THC buildup in the employee, which could indicate over-use problems.

8. One accommodation that should never be permitted is the employee's use of medical marijuana while working. Such could subject the employer to claims that they are facilitating a violation of federal drug laws.

9. Any positions where even slight impairment could be a safety or regulatory violation should not be permitted to use medical marijuana. Should the employee still need to do so, the employer should make an accommodation of permitting the employee to be reclassified to a new position.

Again, the focus of management is that because of the growing tide of laws prohibiting employers from interfering with use of medical marijuana, the employer is taking a "hands-off" approach. They are neither condemning, nor condoning the use of medical marijuana. They are, in effect, remaining neutral to 
what happens outside of work, while still being diligent about work product and safety while the employee is in the workplace.

\section{ENDNOTES}

1. From "Boss of Me", They Might Be Giants. Used as the theme for the TV show "Malcolm in the Middle".

2. Crosgrove, Ariss, Nigem, Wedding, (2016). Workplace Drug Screening: How to Prevent it from Driving Away Millennial Employees, Journal of Leadership, Accountability, and Ethics, Vol 13(2).

3. Coats v. Dish Network, (2015 CO 44, Supreme Court case No. 13SC394) 350 P. $3^{\text {rd }} 849$ (Colo. 2015)

4. I.e. You cannot be fired for doing something off-duty considered legal in Colorado no matter how much your boss disapproves.

5. See Ross v RagingWire Telecom Inc. 42 Cal. 4th 920 (2008)(California); Roe v Teletech Custom Care Mgt LLC 171 Wash 2d 736 (2011) (Washington); Casias v Wal-Mart Stores Inc. 695 F.3rd 428 (6th Cir. 2012) (Michigan); Washburn v Columbia Forest Products Inc. 104 P. $3 \mathrm{~d} 609$ (2005) (Oregon). The state MM statutes in Florida and Montana specifically deny employee rights to sue or receive accommodation. Also see cases collected at 57 ALR 6th 285 (2010)

6. Deitchler, (2015). The Workplace and medical marijuana: Employer guidelines for navigating the legal haze, Insidecounsel.com, assessed 8/12/17 at http://www.insidecounsel.com/2015/04/15the-workplace-andmedical-marjuana-employer-guidepp. Goldsmith (2015), Medical Marijuana in the Workplace, J. Occup Environ Med. 57(5) 518-525, May 2015. A growing minority of states where MM laws forbid adverse employer action, discrimination and/or require employer accommodation include Arizona, Connecticut, Deleware, DC, Illinois, Minnesota, Nevada, New Hampshire, New York, and Rhode Island.

7. Barbuto v. Advantage Sales \& Mktg., LLC, Massachusetts Supreme Court slip opinion, July 18, 2017.

8. OSHA general duty clause: 29 USC Sec. 654(1)(2012). See also Goldsmith, supra at 518.

9. Drug-Free Workplace Act of 1988 Penalties, U.S. Dept. of Labor, accessed 8/12/17 at http://webapps.dolgov/elawsasp/drugfree/penalties.htm

10. Fitting (2106), Careless Conflicts: Medical Marijuana Implications for Employer Liability in the Wake of Vialpando Ben's Automotive Services, 102 Iowa L. Rev. 259.

11. For a more detailed overview covering all of these scenarios, please see Crosgrove, supra.

12. Blake, Andrew, (2017) Americans overwhelmingly favor medical marijuana, split on recreational weed: Poll, The Washington Times, April 18, 2017.

13. Crosgrove, Darrell, (2016). Can Compensation and Benefits Managers Be Personally Liable for FMLA (and FLSA) Decisions? Federal Court of Appeals Says "Yes", Journal of Compensation and Benefits, Vol. 32, No. 3. Sep/Oct. 